\title{
Verification of the technical feasibility of composting: case study
}

\author{
Raounak Edderkaoui ${ }^{1, *}$, Driss Khomsi $^{1}$, Ahmed Hamidi $^{2}$, Hicham Bennani Baiti ${ }^{2}$, Hanane Souidi ${ }^{3} \&$ Mohammed Aqil $^{3}$ \\ ${ }^{1}$ Hydraulic Systems Analysis Team (EASH), Civil Engineering Department, Mohammadia School of Engineers, University \\ Mohammed V in Rabat, BP 765, Rabat, Morocco \\ ${ }^{2}$ EcoMed Group, Morocco \\ 3 3GIE Laboratory, Mineral Engineering Department, Mohammadia School of Engineering, Mohammed V University in Rabat, , BP \\ 765, Rabat, Morocco
}

\begin{abstract}
The aim of this work is to verify the technical feasibility of composting in the case of Marrakech prefecture. On the basis of waste composition and in accordance with the choice of the installation of Marrakech controlled landfill, composting has been considered as the most suitable waste treatment.

To ensure the feasibility of composting, physicochemical analyses have been carried out on the fermentable part of waste; analyses on the content of metal elements have also been performed on the fine fraction, since the most important part is located in the same fraction. All parameters determined in the laboratory, have shown that optimal conditions to have good quality compost have been respected. The only restriction identified is the copper content, which should be less than $20 \mathrm{ppm}$. Generally the low levels of metal element content indicate that the storage and collection conditions of waste have not influenced their quality. On the other hand, the process must be properly controlled and managed, to produce high-quality compost.
\end{abstract}

\section{Introduction}

Population growths combined with industrial development have caused an evolution in the production of waste [1]. The issue of solid waste management is the most pressing challenge for authorities in small and large cities of developing countries [2]. To face this problem, the majority of waste must be recovered in order to reduce the amount of waste to be landfilled, as well as to protect the natural environment.

The predominant municipal solid waste treatment and disposal facilities are composting, mechanical and biological treatment, recycling, energy recovery and landfilling [3]. The choice of the suitable recovery option depends on several social, economic, geographical and technical parameters. Of all recycling methods, composting has been strongly recommended due to its environmental and economic benefits [4-5]. The addition of compost to soil gives nutrients for plant growth, enhances soil structure, and increases water retention capacity [6-7-8].

The complex and heterogeneous nature of moroccan waste creates a number of difficulties for its treatment and management. A large part is landfilled unprecautionary, which constitutes a real and permanent environmental challenge [9]. However, the majority of waste can be recoverable, considering their chemical nature, their characteristics and their physicochemical properties [10-11]. Marrakech is one of moroccan cities that is looking to enhance its waste sector, and to extend the life of its controlled landfill. In this context, a study of waste composition has been carried out in Marrakech by Edderkaoui et al. [11] in order to identify the best treatment and recovery options.

On the basis of waste composition and characteristics, and in accordance with the choice of the installation of Marrakech controlled landfill, the suitable treatment methods obtained are composting and recycling. The production of high quality compost requires that the process be properly controlled and managed [12] Temperature, $\mathrm{pH}$, moisture content and carbon-nitrogen ratio $(\mathrm{C} / \mathrm{N})$ are the most important parameters contributing to the effectiveness of the composting process [13]. $\mathrm{PH}$ is associated with microbial growth and ammonia emission, moisture content strongly affects the physical and chemical properties of raw materials, the $\mathrm{C} / \mathrm{N}$ ratio is important for microbial growth and aeration has a great impact on microbial growth and gas emission.

For this purpose, a bibliographical study has been carried out on the factors influencing composting as well as the quality of compost, in order to orientate the work towards the analyses to be carried out so as to study the technical feasibility of composting. In this context, physicochemical analyses have been carried out on the fermentable part of waste as well as analyses on the content of metal elements have been performed on the fine fraction, since the major part is located in the very same fraction.

\section{Literature review}

Composting deals with fermentable waste that poses particular challenges for transformers [14]. Composting reduces the amount of waste destined for landfill, groundwater contamination, air pollution and greenhouse gases emissions and it produces valuable products [15]. The produced compost, which is relatively rich in humic substances, represents an excellent soil conditioner. It improves the physical, chemical and biological properties of the soil [16].

Corresponding author: raounak.ed@gmail.com 


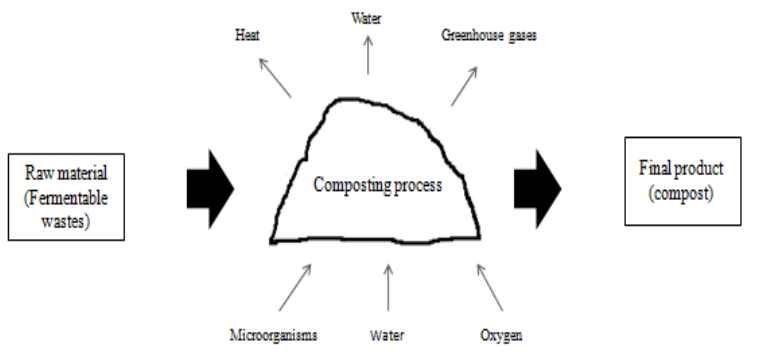

Fig. 1. Composting process.

\subsection{Factors influencing composting}

The most significant factors influencing composting process are temperature, moisture content, $\mathrm{pH}$, aeration rate, Carbon/Nitrogen ratio, particle size [17]. In fact, as quickly as the physicochemical conditions permit, microorganisms constitute a complex flora which is rapidly starting up [18].To achieve compost maturity, physicochemical parameters must be well identified and controlled [14-19-20-21].

\subsubsection{Temperature}

The temperature varies during the three stages of composting (thermophilic, mesophilic and salting (Rui [22]. Pace et al. [23] have indicated that composting of organic waste is performed between two temperature profiles, one thermophilic and the other mesophilic. The decomposition begins in a thermophilic environment [24]. In fact, the evolution of temperature is an important parameter for microbial activity during composting, and is therefore considered a practical parameter to assess the state of composting processes [25]. Bertoldi et al. [26] reported that the temperature maintained between $45^{\circ} \mathrm{C}$ and $55^{\circ} \mathrm{C}$ was the optimal temperature for the composting process. Many studies have recommended the use of external heating equipment, which is fast, but the results obtained are seldom satisfactory, because the rapid increase in temperature due to external heating may not be beneficial for microorganisms growth [14].

\subsubsection{Carbon/Nitrogen}

The carbon/nitrogen $(\mathrm{C} / \mathrm{N})$ ratio is one of the key factors that impact the composting process as well as the final product characteristics [27]. The determination of an optimal $\mathrm{C} / \mathrm{N}$ ratio is of great importance for obtaining a suitable composting results, and is strongly dependent on the properties of materials used [28]. Kavitha and Sabramarian [29] reported that the ideal C/N at the start of the composting process would be less than 30 and at the end it would need to be decreased to 20 . Organic materials that have a high $\mathrm{C} / \mathrm{N}$ ratio can be adjusted to promote good composting [26]. A high initial $\mathrm{C} / \mathrm{N}$ ratio leads to a longer composting time, while a low initial $\mathrm{C} / \mathrm{N}$ ratio produces high levels of volatile gas and leachate emissions [30].

\subsubsection{PH}

The required $\mathrm{pH}$ level for microbial activity is in the range of $5-7$; however, for composting an optimal $\mathrm{pH}$ is between 5.5 and 8.5 [31]. In general, the $\mathrm{pH}$ begins to decrease at the beginning of composting process, as a consequence of the activity of acidogenic bacteria which decompose complex carbonaceous materials to intermediate organic acids [26]. Generally, $\mathrm{pH}$ variation is highly dependent on the buffer capacity of additives and the production of organic acid and ammonia; maintaining $\mathrm{pH}$ at a desirable level will help to reduce composting time and enhance its performance [14].

\subsubsection{Moisture content}

The moisture content is an essential composting factor; it has the most meaningful impact on almost all other physical parameters [32]. Moisture content provides a transportation means for dissolved nutrients necessary for metabolic and physiological activities of microorganisms [14]. Moisture content also influences the physical and chemical properties of waste during the decomposition of organic matter [33].

The optimal moisture content in composting is variable and primarily depends on the physical condition and particle size [26]. The most suitable moisture level for biodegradation of different compost mixtures ranges from $50 \%$ to $70 \%$ [33]. Other researchers have suggested moisture content around 55 to $60 \%$ [34].

\subsubsection{Aeration}

Composting is a biological oxidation, and the availability of oxygen during the process is of paramount importance. The aeration rate influences biological activity during the composting process [35]. Low and medium aeration rates cause an increase in the percentage of total nitrogen, a significant decrease in the $\mathrm{C} / \mathrm{N}$ ratio and a long time duration of the thermophilic phase, whereas high aeration rates led to a higher electrical conductivity value for compost slurry [36]. Several systems have also been applied to provide aeration for composting: rotating mechanical and forced ventilation via a fan [31].

The oxygen content of the circulating air should not be less than about $18 \%$ [26].The oxygen concentration inside the compost could be well controlled by adjusting the aeration rate [14].

\subsection{Compost quality}

\subsubsection{Heavy metals}

Composting is a very sensible process because it reintroduces into the food chain part of waste material that users have removed, hence the need to produce good quality compost that does not pose threats to consumer health and preserves the natural environment.

The content of metal elements in the waste can negatively affect compost quality. The heavy metal 
content is highly influenced by the impurities present in the raw solid and municipal waste [12]. Heavy metal concentrations are expected to accumulate in soils after long-term application of waste compost; it can even reach groundwater [5-37-38]. Several process control measures will help to reduce heavy metal concentrations in waste to be composted, such as source separation, advanced mechanical segregation and product refinement by removing fine particles enriched with heavy metals through screening [39]. Source separation is generally considered the most efficient and promising method to improve compost quality in terms of metal content [37]. On the other hand, research has shown that it is possible to improve the quality of compost by shredding it to a particle size of more than $0.8 \mathrm{~mm}$ [12]. In an attempt to minimize the risks associated with heavy metals in soil, most countries use their own government controls over commercial compost production in the form of regulations or guidelines [5].

\subsubsection{Maturity and stability}

The use of both maturity and stability indicators is reported as the most appropriate parameter for compost quality assessment [12].

Maturity is a general term describing the suitability of a compost for a specific end use, it is generally associated with plant growth potential or phytotoxicity[40]. Stability can be defined as the degree of decomposition of a biodegradable material [41].

The unavailability of universally accepted maturity and stability indices has generated a wide variety of innovative methods for assessing maturity and stability [12].

One of the most important methods for determining stability is the use of respirometric techniques to measure $\mathrm{CO} 2$ production and consumption, also heat production [12-42].

\section{Material and methods}

\subsection{Study area}

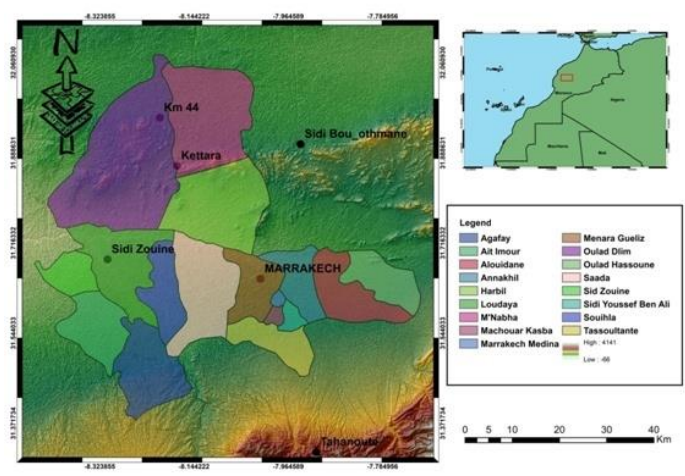

Fig.2. Geographical situation of the study area.
The prefecture of Marrakech is an urban subdivision of Marrakech-Safi region. It mainly contains the city of Marrakech and 13 rural municipalities around the city. The city of Marrakech is subdivided into 2 municipalities: the municipality of Méchouar Kasbah and the municipality of Marrakech, which is divided into five main districts.

\subsection{Waste composition study}

The identification of waste composition and characteristics is a key element in the choice of the most suitable treatment options [43]. To this end, a waste characterization method has been developed for the case of Marrakech prefecture, based on studies that have been carried out in different countries as well as budgetary and technical limits [11]. The characterization results allow to confirm the choice of composting as the best waste treatment.

\subsection{Physicochemical analyses}

Based on the characterization results of the prefecture of Marrakech [11], composting has been considered the most appropriate recovery option. To ensure the feasibility of composting, physicochemical analyses have been carried out on the fermentable part of waste; analyses on the content of metal elements have also been performed on the fine fraction, since the most important part is located on the fraction of fermentable material less than $80 \mathrm{~mm}$

\section{Results and Discussion}

\subsection{Waste production in Marrakech prefecture}



Fig.3. Daily production of waste in the prefecture of Marrakech.

Fig. 3 shows the amount of waste daily generated according to the productive parts in Marrakech Prefecture. Waste of the city of Marrakech is mainly present $(862,70 \mathrm{t} / \mathrm{d})$, then comes waste of the municipalities that are around the city $(56,43 \mathrm{t} / \mathrm{d})$, while private company produces only $(0,36 \mathrm{t} / \mathrm{d})$. 


\subsection{Average composition of waste in the prefecture of Marrakech}

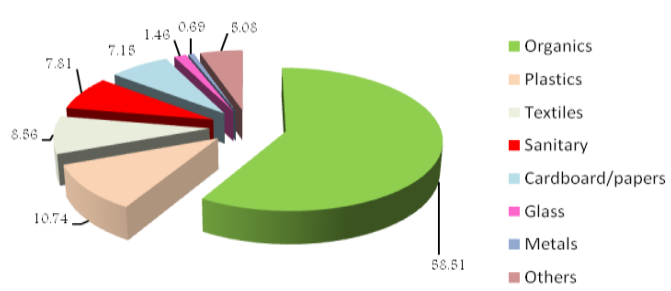

Fig.4. The average composition of waste in the prefecture of Marrakech.

Fig. 4 shows the average composition of Marrakech prefecture waste: generally, waste is characterized by the predominance of organics $(58.51 \%)$, a relatively important presence of plastics $(10,74 \%)$, textiles $(8$, $56 \%)$, sanitary $(7,81 \%)$, cardboard/papers $(7,15 \%)$, as well as a small quantity of other waste $(5,08 \%)$, glass $(1$, $46 \%$ ) and metals $(0,69 \%)$.

\subsection{Waste production per person in Marrakech prefecture}

Table 1. Daily and annual production of waste per person.

\begin{tabular}{|l|l|l|}
\hline Categories & $\begin{array}{l}\text { Ratio } \\
\mathrm{Kg} / \text { per/day }\end{array}$ & $\begin{array}{l}\text { Ratio } \\
\mathrm{Kg} / \text { per/year }\end{array}$ \\
\hline Organics & 0,40 & 145,22 \\
\hline Plastics & 0,07 & 26,66 \\
\hline Textiles & 0,06 & 21,25 \\
\hline Sanitary & 0,05 & 19,38 \\
\hline Cardboard/papers & 0,05 & 17,75 \\
\hline Glass & 0,01 & 3,62 \\
\hline Metlas & 0,00 & 1,71 \\
\hline Others & 0,03 & 12,61 \\
\hline
\end{tabular}

The calculation of the ratio (Kg/person) of the Marrakech prefecture has allowed knowing the quantity produced of each waste category per person. This estimate has been based on the composition of waste weighted by the waste production rate per person calculated from census data.

Analysis of the table 1 shows that: each person produces per day $0.40 \mathrm{~kg}$ of organics, $0.07 \mathrm{~kg}$ of plastic, $0.06 \mathrm{~kg}$ of textile, $0.05 \mathrm{~kg}$ of cardboard/paper, while other wastes are generated at small amounts.

\subsection{Production of fermentable waste per person per year}

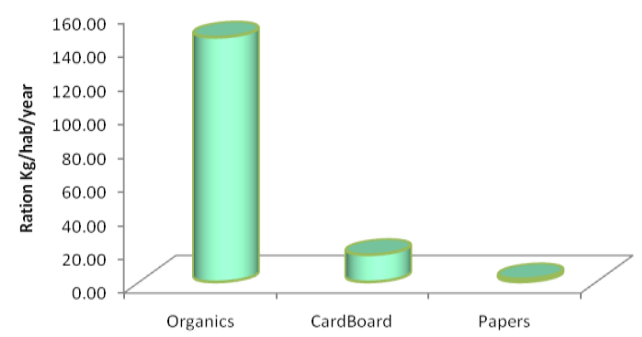

Fig.5. Fermentable waste generation per person per year.

Composted waste includes the biodegradable part, which is composed mainly by organics, cardboard and papers. Fermentable waste is mainly present in Marrakech prefecture waste; it represents $65.66 \%$ of the overall of waste, as well as each person produces $162.96 \mathrm{~kg}$ of fermentable waste per year.

\subsection{Physicochemical analysis results}

Table 2. Results of physicochemical analyses.

\begin{tabular}{|c|c|c|}
\hline Nomination & Values & Unit \\
\hline Density & 0.37 & $\mathrm{t} / \mathrm{m}^{3}$ \\
\hline Moisture content & 59 & $\%$ \\
\hline Organic matter & 69.41 & $\mathrm{~g} / 100 \mathrm{~g}$ \\
\hline C/N & 28,78 & $\mathrm{~g} / 100 \mathrm{~g}$ \\
\hline
\end{tabular}

The main parameters that have been determined at the laboratory are: density, moisture content, organic matter, carbon and nitrogen. Optimal conditions for fast composting require a $(\mathrm{C} / \mathrm{N})$ ratio between 25 and 35 , a moisture content between $45 \%$ and $60 \%$, bulk density less than $0,45 \mathrm{t} / \mathrm{m} 3$ [44].

Based on the results of physicochemical analysis showed in table 2, optimal conditions for obtaining good quality compost have been respected.

\subsection{The content of metal elements in the fine fraction of waste}

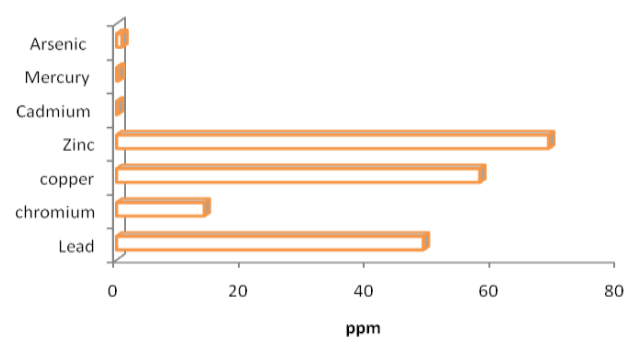

Fig.6. Metal element contents in the fine fraction of waste. 
Generally, the highest content of metal elements is found in the fine fraction. For this purpose, analyses have been carried out only on the fine fraction with a diameter less than $80 \mathrm{~mm}$ [11]. Results reveal that metal elements content within the fine fraction does not exceed the recommended limits; except copper content which must be less than $20 \mathrm{ppm}$.

\section{Discussion}

Based on the characterization results of Marrakech prefecture waste (predominance of organics, low presence of recyclable products, as well as combustible products) [11], and the high needs of poor and degraded soils for organic matter, composting has been selected as the most appropriate treatment option. Composting is known for its considerable importance in waste treatment, due to its benefits in reducing the volume of waste, improving soil structure, as well as improving the environment through the reduction of greenhouse gases emissions.

Morocco has installed several composting plants but has not succeeded in this field, due to the frequent failures produced, the poor quality of compost, the marketing compost, as well as other environmental nuisances (bad odours, leachate)[45]. These composting plants have been implemented, without any prior configuration of the treatment parameters (sorting efficiency, composting soot, temperature control, and air injection). In this context, physicochemical analyses have been carried out to verify the technical feasibility of composting in the prefecture of Marrakech. Generally, the results showed that composting is feasible, as well as the content of metal elements within the fine fraction does not exceed the recommended limits, except copper content, it may blocks iron absorption by plants [46]. Generally, even within legal limits, heavy metals are anticipated to accumulate in soils or plants following the long-term application of waste compost [38]. To have good compost, it is preferable to implement composting with waste separation systems at source, so that they do not mix with other waste types [5]. In fact, waste separation at source provides good quality compost compared to mechanical separation [47]. On the other hand, research has shown that it is possible to improve the quality of compost by grinding the compost to a particle size of more than $0.8 \mathrm{~mm}$ [48].

Thus a compost classification based on the concentration of heavy metals is strongly recommended, for example, it is strongly recommended that composted materials from mixed waste not be used as real compost in agriculture [5].

On the other hand, compost marketing has a key role in the success of composting projects. To this end, two essential objectives must guide the marketing of compost: Sale of the whole volume of compost produced, and income optimization and cost minimization [49]. Thus, logistical means must be considered in the design of composting units, to facilitate the transport of the compost produced to the concerned parties.

\section{Conclusion}

The purpose of this study is to verify the technical feasibility of composting in the case of Marrakech prefecture. The characterization results showed that Marrakech waste is dominated by organic matter which confirms the choice of composting as the most suitable waste recovery option. The classification of waste per person has allowed knowing the waste generated by category in relation to each person, which will help in the good planning of waste management. In order to verify the technical feasibility of composting, physicochemical analyses have been carried out on the compostable waste. The results showed that composting is achievable, as well as the content of metal elements within the fine fraction does not exceed the recommended limits, except the copper content, which indicates that the collection and transport conditions have not influenced the quality of fermentable waste. Wherever, it is highly recommended to implement composting with waste separation systems at source, so that they do not mix with other types of waste, which will help to produce good quality compost. Thus a classification of compost, based on the concentration of heavy metals, will be of great importance in compost utilization. The commercialization of compost will also play a significant role in the success of composting plants.

\section{References}

1- A. Minelgaitè, G. Liobikienè, Sci. Tot. Environ. 667, 12 (2019)

2- H. I. Abdel-Shafy, M.S.M. Mansour, Egy. J. Petro. 27, 15 ( 2018)

3- C. S. Psomopoulos, A. Bourka, N.J. Themelis, CEMEPE (2007)

4- F. Lei, J.S. VanderGheynst, Pro. Bio. 35, 6 (2000)

5- Y. Wei, J. Li , D. Shi, G. Liu, Y. Zhao, T. Shimaoka, Resear. Cons. Recyc. 122, 14 (2017)

6- C. P. Jordão, C. C. Nascentes, P. R. Cecon, R. L. F. Fontes, J. L. Pereira, Environ. Monit. Assess. 112, 17 (2006)

7- Z.Q. Chen, S.H. Zhang, Q.X. Wen, J. Zheng, J. Environ. Sci. 37, 6 (2015)

8- A. Fernández-Hernández, A. Roig, N. Nuria Serramiá, C. García-Ortiz Civantos, M. A. Sánchez-Monedero, Waste Manage. 34, 8 (2014)

9- H. Chtioui, F. Khalil, S. Souabi, MA. Aboulhassan, Déch. Sci. Tech. (2008)

10- C. J. Jung, Scientific Bulletin of the National Institute for the Environment and Nature Conservation, 12 (2013) 
11- R.Edderkaoui, D.Khomsi, A.Hamidi, H.Bennani Baiti, Int. Rev. Civ. Eng. 10 ,6 (2019)

12- A.Cerda, A. Artola, X. Font, R.Barrena, T.Gea, and A.Sanchez, Bioresour. Technol. 248, 10 (2018)

13- A. A. Kadir, N. W. Azhari, S. N. Jamaludin, , MATEC Web of Conferences, 47 (2016)

14- L. Zhentong, L. Hongwei, L. Ren, L. He, Chemos.93, 10 (2013)

15- D. Cekmecelioglu, A. Demirci, R.E. Graves, N.H. Davitt, Biosyst. Eng. 91, 7 (2005)

16- P. Giloux, Les Finalités du Compostage (T.S.M., 1995)

17- B. K. Adhikari, S. Barrington , J. Martinez , S. King, Waste Manag. 28, 9 (2008)

18- S. Aboulam, Recherche d'une method a'analyse du fonctionnement des usines de tri-compostage des déchets ménagers. Fiabilité des bilans matiéres- (Ph.D. dissertation, Toulouse, 2005)

19- D. P. Komilis, R. K. Ham, J. K. Park, Water Resear. 8, 7 (2004)

20- I.J. Chang, J.Y. Chen, Bioresour. Technol.101, 7 (2010)

21- J. Huet, C. Druilhe, A. Trémier, J.C. Benoist, G. Debenest, Bioresour. Technol. 114,8 (2012)

22- R. Guo, G.X. Li, T. Jiang, F. Schuchardt, T.B. Chen, Y.Q. Zhao, Y.J. Shen, Bioresour. Technol. 112, 7 (2012)

23- M.G. Pace, B.E. Miller, K.L. Farrel-Poe, The composting process (AG-WM01, 1995). Available online at www.extension, usu.edu/files/agpubs/agwmo1

24- R. Shahid, A. Jalil, Inter. J. Biol. Resear. 4, 2 (2016)

25- J. C. Tang, A. Shibata, Q. Zhou, A. Katayama, J. Biosci. Bioeng.104, 7 (2007)

26- M. de Bertoldi, G. Vallini, A.Pera, Waste Manag. Resear. 1, 19 (1983)

27- J.I. Chang, T.E. Hsu, Bioresour. Technol. 99, 6 (2008)

28- B. Adhikari, S. Barrington, J. Martinez, S. M. King, Waste Manag.28, 9 (2008)

29- R. Kavitha, P. Subramanian, J. Appl. Sci. 7, 4 (2007)

30- B. J. Young, P. F. Rizzo, N. I. Riera, V. D. Torre, V. A. López, C. D. Molina, F. E. Fernández, D. C. Crespo, R. Barrena, D.Komilis, A. Sánchez, Waste Manag. 54, 8 (2016)

31- K.R. Atalia , D.M. Buha, K.A. Bhavsar, N.K. Shah, J. Environ.Sci. Toxic. Food Technol. 9, 9 (2015)

32- M. Kumar, Y.L. Ou, J.G. Lin, Waste Manag. 30, 7 (2010)

33- M.K. Iqbal, T. Shafiq, K.Ahmed, Bioresour. Technol. 101, 6 (2010)

34- C. LIANG, K. C. DAS, R. W. MCCLENDON, Biorsour. Technol. 86, 6 (2003)

35- M.Gao, B. Li, A. Yu, F. Liang, L. Yang, Y. Sun, Bioresour. Technol. 101, 4 (2010)
36- M. Rasapoor, T. Nasrabadi, M. Kamali, H. Hoveidi, Waste Manag. 29, 3 (2009)

37- A. Veeken, B. Hamelers, Sci. Tot. Environ. 300, 11 (2002)

38- F. Madrid, R. Lopez, F. Cabrera, Agr. Ecosyst. Environ. 119, 7 (2007)

39- T.L.Richard, P.B.Woodbury, Biomass and Bioenergy 3, 16 (1992)

40- D.A. Iannotti, T. Pang, B.L. Toth, D.L. Elwell, H.M. Keener, H.A.J. Hoitink, Compost Sci. Utiliz. 1, 13 (1993)

41- R. Barrena, F. Vázquez, A. S. Ferrer, Waste Manag. Resear. 24, 10 (2006)

42- D. Komilis,C. Kletsas, Bioresour. Technol. 121, 3 (2012)

43- M. S. Korai, R. B. Mahar, M. A. Uqaili, Renew. Sust. Ener. Rev. 72, 15 (2017)

44- R. Leslie, Lab. Medicine 31, 7 (2000)

45- S. Ben Ammar, Challenges of the characterization of household waste for the choice of adapted treatments in developing countries- Results of the characterization in Greater Tunis development of a suitable method (Ph.D. dissertation, Nancy, 2006)

46- Association Blé Dur Développement, 4,4 (2018)

47- T. Kupper, D. Bürge, H. J. Bachmann, S. Güsewell , J. Mayer, Waste Manag. 34, 7 (2014)

48- X. He, S. Logan, S. Traina, J. Environ. Qual. 24, 9 (1995)

49- B. SOUDI, H.T.E. (2001) 